\title{
QUANDO FILMES SÃO PALAVRAS: UMA INTRODUÇÃO AOS ESTUDOS DE ROTEIRO
}

\author{
WHEN FILMS ARE WORDS: AN INTRODUCTION TO \\ SCREENWRITING STUDIES
}

Pablo Gonçalo'

\begin{abstract}
RESUMO: Este artigo realiza uma introduçăo aos estudos de roteiro, os quais, há cerca de uma década, vem se estabelecendo com um grupo de publicaçōes, pesquisas, revistas acadêmicas, e de congressos periódicos. Apresentaremos os principais autores, conceitos, metodologias e tópicos de debates do campo chamado Screenwriting Studies. Dividimos o artigo em quatro seçôes, se ndo que na primeira salientamos uma periodizaçâo histórica da prática do roteiro dentro da história do cinema; na segunda, abordamos autores roteiristas, conceitos e metodologias; na terceira e na quarta elaboramos uma crítica reflexiva do campo dos estudos de roteiro e sugerimos uma contribuiçăo que compreenda o roteiro como uma prática escrita intermedial além de iniciamos uma aproximaçăo entre o roteiro e o debate sobre ekphrasis.
\end{abstract}

Palavras-chave: Estudos de roteiro; História do cinema; Intermedialidade.

ABSTRACT: This article is an introduction to the Screenwriting Studies, which has been established with a group of publications, research, academic journals and periodical congresses. I will present the main authors, concepts, methodologies and discuss topics of that field. Therefore, I divide the article into four sections. The first will emphasize a historical periodization of script practice within the history of cinema; In the second, I approach authors as well as writers, concepts and methodologies; In the third and fourth I elaborate a reflexive critique of the field of screenwriting studies and suggest a contribution that understands the script as an intermedial gesture and writing practice. Finally, I propose an approximation between the script and the debate about ekphrasis

Keywords: Screenwriting studies; Film history; Intermediality.

\section{Introdução}

Adaptaçăo (2002), de Spike Jonze, inicia-se com uma curiosa sequência, que é também bastante reveladora. Entra-se num set de filmagem, numa típica cena de

\footnotetext{
Professor adjunto de audiovisual da Faculdade de Comunicaçăo (FAC), da Universidade de Brasília (UnB). É autor do livro 0 cinema com o refúgio da escrita: roteiro e paisagem em Peter Handke e Wim Wenders (Annablume, 2016). É curador, roteirista e crítico de cinema da Revista Cinética. Possui publicaçôes em revistas internacionais como Journal of Screenwriting e periódicos brasileiros, como Galáxias e Rebeca, entre outros. É membro e participa de congressos da SCMS, Society for Cinema and Media Studies, da Screenwriting Research Network, da SOCINE e da Compós.
} 
metalinguagem que aos poucos revela facetas mais inusitadas. Além do diretor, dos atores, dos demais técnicos de fotografia e som também surge uma figura um tanto deslocada: vê-se Charlie Kaufman (Nicolas Cage), que curiosamente é o roteirista autor e personagem - que, de forma insistente, quer dar alguns palpites nas cenas que escreveu para o filme. Suas sugestóes, no entanto, săo desastradas e causam mais problemas de filmagem do que soluçōes técnicas. Com o script nas măos, Kaufman emerge como um sujeito onírico, complicado, um sujeito imerso no mundo das letras e completamente alheio ao pragmático cotidiano do set. Aos poucos, enquanto os créditos do filme ainda sobem, os técnicos, a produçăo e o diretor tomam uma decisáo. Nâo há ali, e naquele contexto, espaço para Kaufman. Eles pedem para Kaufman retirar-se. Fecha-se a porta do estúdio. Findos os créditos e o roteirista já năo faz mais parte do set. Inicia-se, enfim, o filme.

O roteirista, nessa notável e cômica sequência, melhor situa-se quando fora do set. Embora o contundente recado do próprio roteirista Kaufman seja destinado à indústria cinematográfica, podemos, tranquilamente, estendê-lo ao campo dos estudos de cinema, à literatura e aos diálogos intermediais entre essas duas linguagens e tradiçôes. Assim como o roteiro costuma năo ter lugar num set de filmagem ele tampouco parece habitar as ciências humanas: sâo um arquivo marginal. Trazer o roteiro para o cerne de uma análise fílmica é algo que ocorre de forma totalmente ocasional e esporádica. Estas linhas e este artigo, contudo, pretendem apontar uma pequena, sutil e pontual mudança nesse cenário. Como salientaremos, aos poucos alguns pesquisadores iniciaram uma crescente valorizaçăo conceitual, histórica e mesmo epistemológica sobre o papel do roteiro. O objetivo desse artigo é apresentar, de forma breve e sucinta, essas questôes e compartilhar parte da sua contribuiçăo nas pesquisas que cotejam cinema, escrita e narrativas por meio da perspectiva e do fio histórico propiciado pela prática do roteiro.

\section{Histórias ao invés de (apenas) story}

Mais história do que simplesmente estórias audiovisuais. Com uma simples sentença alcança-se a síntese dos objetivos dos estudos de roteiro. Como detalharemos logo abaixo, suas primeiras pesquisas evidenciavam um forte interesse em delimitar uma linha cronológica da forma como o roteiro consolidou-se, historicamente, dentro do próprio cinema, como instituiçăo e, curiosamente, também como um discurso de história. Como os primeiros realizadores escreviam suas estórias? Como a maneira de narrar essas estórias foram alterando os gêneros cinematográficos? De que forma os roteiristas dialogaram com o teatro, a literatura e outras formas de escrita e narrativa do seu tempo? Quais foram e sâo os principais roteiristas-autores da história do cinema? Como os roteiristas lidam com a indústria?

Como se vê, essas nâo sâo perguntas triviais e elas impelem a uma agenda prédefinida, que reivindica um hercúleo esforço coletivo e permeia - e pautará - a carreira de inúmeros pesquisadores. Há pouco mais de uma década, o campo dos estudos de roteiro era totalmente restrito aos conceitos e às formulaçôes oriundas dos manuais. Seja nas universidades, nos cursos livres de cinema ou nos núcleos de dramaturgia de televisóes, o vocábulo roteiro costuma ser unicamente vinculado a técnicas e formas de se contar uma "boa estória". Sảo mais artimanhas, regras, ditames estéticos e trejeitos 
no modo de contar estórias do que propriamente a história que permitiu contá-las. Embora seja válida e seminal, essa inquietaçâo dos manuais de roteiros cinematográficos é apenas uma das vertentes possíveis dos tantos temas e pesquisas que vem, desde 2007, consolidando o chamado campo dos estudos de roteiro, ou Screenwriting Studies, como esse campo intitulou-se dentro dos estudos de cinema.

Durante a última década, houve, dentro do ambiente acadêmico de língua inglesa, um número crescente de pesquisas, publicaçóes e trabalhos diversos mais especificamente dedicados à historiografia e aos conceitos concernentes aos roteiros. Embora o campo seja realmente incipiente, ele, aos poucos, consolida-se e hoje já esboça uma série de conceitos mais fundamentais, periodizaçóes razoavelmente consolidadas sobre a história do roteiro, conta com um encontro anual, desde 2007, como o Screenwriting Research Network (SRN), uma revista acadêmica totalmente dedicada à publicaçáo de artigos que se debruçam sobre análise de roteiros e de obras de roteiristas, com o nome de Journal of Screenwriting e vigente desde 2010, e uma linha editorial bem definida, que organiza, publica e divulga para um público mais amplo os trabalhos mais importantes desse campo, como é o caso da coleçăo Screenwriting Studies, da editora Palgrave. ${ }^{2}$

Curiosamente, o cerne desses grupos de pesquisa transita por países como a Inglaterra, a Austrália, Bélgica, Holanda, Alemanha e Finlândia. Por outro lado, os principais autores e teóricos, desse novo campo - dentre os quais destacamos os nomes de Steven Maras, Steven Price, Ian W. MacDonald, Kathryn Millard - foram exímios em revisar parte da bibliografia já esparsa e presente a, qual, sintomaticamente, é oriunda de pesquisas realizadas em universidades norte-americanas. Embora privilegie a história dos roteiros em Hollywood e nos estúdios (e países) europeus, essa revisăo bibliográfica, mais atualizada, permitiu compilar os primeiros manuais de roteiro ainda na segunda década da história do cinema, o surgimento de publicaçóes de antologias de roteiros, no auge dos anos sessenta, assim como as pesquisas mais sistemáticas que, dentro do mundo acadêmico, começaram a surgir a partir dos anos oitenta e noventa. ${ }^{3}$

Como todo o campo acadêmico emergente, os estudos de roteiro vêm compartilhando sobretudo uma agenda de questōes, temas de pesquisa e possíveis vertentes metodológicas que ainda permanecem bastante ancilares. Sequioso por uma primeira periodizaçáo e conceituaçáo do roteiro, o pesquisador australiano Steven Maras realizou năo apenas um estudo do modo como haveria uma roteirizaçáo no período conhecido como primeiro cinema, como também analisou os primeiros e mais famosos manuais de roteiro. Nos Estados Unidos, os manuais de roteiro surgiram desde 1911. Tido como um grande best-seller da sua época, The Technique of the Photoplay 1913, de Epes Winthrop Sargent já apontava uma tendência aristotélica de escrita para as telas e orientava, de forma próxima a um diálogo, jovens a buscarem suas próprias narrativas para as telas. Ainda náo havia a figura histórica do roteirista - que só veio

\footnotetext{
2 Sugiro que o leitor acesse as páginas eletrônicas da SRN e da Revista Acadêmica para ter um contato direto com a apresentação de cada uma dessas instituiçōes. Disponível em:<http://screenwritingresearch. com/>; <https://www.intellectbooks.co.uk/journals/view-Journal,id=182/>.

3 Para uma síntese das bibliografias e uma primeira história dos manuais de cinema, cf.: MARAS, 2008 e PRICE, 2013.
} 
a se consolidar de fato na década seguinte e a tomar a forma que conhecemos a partir do cinema sonoro.

Nesse contexto emergente da própria história do cinema, a escrita fundia-se diretamente com o ato de filmar. Assim, naquela época, a escrita para e com filmes estaria mais próxima do que hoje chamamos como uma escaleta. Maras, no entanto, salienta um aspecto positivo desse momento e, a partir das análises dos princípios estéticos de escrita fílmica de Victor O. Freeburg e Vachel Lindsay, ele realça que se escrevia, no início do século XX, de uma maneira bem próxima ao modo como atualmente lida-se com as mídias técnicas. ${ }^{4}$ Mais do que o roteiro, no sentido de uma escrita específica e em papel (que ele denomina como paper based), Maras realça como houve, previamente, a consolidaçăo de práticas de escrita fílmica vinculadas diretamente às de filmagens e de montagem.

Aos poucos, Maras também esboça uma primeira periodizaçăo da prática dessa escrita fílmica, até a consolidaçăo dos roteiros e dos roteiristas. Seminais, os resultados das pesquisas de Janet Staiger sobre o cinema clássico de Hollywood propiciaram as diretrizes da primeira periodizaçăo da história do roteiro (BORDWELL, STAIGER, THOMPSON, 1985). Sua divisăo do modo de produçăo - econômico, social e artístico - de Hollywood permitiu um delineamento das práticas, das regras, das convençôes e dos formatos de trabalho de criaçăo dramatúrgica dentro dos estúdios próximos a Los Angeles. Numa palavra: descobriu-se como os roteiristas se incorporaram antes, durante e depois da consolidaçăo do sistema de estúdios. Nessa linha, dos primórdios do cinema até 1960, desenharam-se seis distintas configuraçóes históricas. Haveria, segundo Staiger, no chamado primeiro cinema, 1896-1907, o sistema do cameraman; em seguida, inicia-se o sistema do diretor, de 1907-1909, que se torna mais profissional entre 1909-1914, culminando no sistema unitário do diretor. A partir de 1914, inicia-se a proeminência do produtor, no modelo do sistema central do produtor, que termina em 1931 e permite, após o advento da tecnologia sonora, o sistema unitário do produtor indo até 1955. Nos últimos cinco anos da chamada era de ouro de Hollywood, até 1960, consolida-se o chamado Package-unit system.

Embora a descriçăo historiográfica de Staiger culmine com o fim da chamada era de ouro dos estúdios, ela foi essencial para a compreensâo dos delineamentos entre os formatos narrativos e as configuraçóes socioeconômicas que atravessaram os estúdios por aquelas décadas. Dos anos sessentas em diante, por exemplo, houve mudanças estruturais que, com o advento da "Nova Hollywood" e das universidades de cinema, representaram alteraçôes, além da emergência de um diferente mote de profissionalizaçâo do roteiro. Surge, de um lado, a figura do roteirista independente dos estúdios ou mesmo autor-roteirista, bem representada pelas trajetórias de Francis Ford Coppola, Martins Scorsese e seus colaboradores mais imediatos, como Paul Schrader (NORMAN, 2008). Simultaneamente, por outro lado, há uma busca por novas formas de produçâo e de encadeamento narrativo que é notável no início das carreiras de Georges Lucas e Steven Spielberg, onde a dramaturgia fílmica aproxima-se dos três atos, dos

Cf.: MARAS, Steven. The photoplay as emergent media form: Victor O. Freeburg and Vachel Lindsay on photoplay aesthetics <http://www.screeningthepast.com/2014/12/the-photoplay-as-emergent-mediaform-victor-o-freeburg-and-vachel-lindsay-on-photoplay-aesthetics/>. 
personagens com interioridade psicológica e com percursos próximos a uma narrativa mitológica. Esses motes, inclusive, foram utilizados, definidos e disseminados pelos manuais de Syd Field, no final dos anos noventa (PRICE, 2013). ${ }^{5}$

Em cada um desses momentos, as formas de escritura do roteiro ora sâo mais presentes, ora, como no Cameraman system (a qual pressupóe o entrelaçamento individual entre o sujeito que filma o que escreve e o que dirige) tendem a desaparecer. De forma a aproximar esse recorte temporal às práticas efetivas de roteirizaçăo em Hollywood, Steven Maras ressalta três instantes distintos. O primeiro acena para uma crescente institucionalizaçăo da prática cinematográfica que, como se percebe, ocorre a partir de 1907 (MARAS, 2009, p. 16). Em seguida, há, de fato, o surgimento do roteiro, próximo ao formato que hoje conhecemos, até tornar-se um valioso instrumento de planejamento industrial enfaticamente apreciado pelos produtores e outros executivos dos estúdios. O terceiro e último instante é um claro desdobramento do segundo, quando o roteiro de fato se torna a peça central de planejamento dos custos e riscos da produçăo. É o chamado roteiro blueprint, o qual, segundo os rígidos ditames do estúdio, deveria ser filmado exatamente como estava expresso e previsto no roteiro. No modelo do blueprint, os departamentos de roteiros ganham maior relevância, uma árdua metodologia e divisâo de trabalho e buscam uma aproximaçấo bem específica e pragmática com a literatura norte-americana contemporânea a esses modelos.

Indo um pouco além dessa primeira periodizaçăo de Staiger, Steven Maras e Steven Price salientam algumas nuances, certas sutilezas e, paulatinamente, começam a sair de uma análise centrada exclusivamente na experiência de Hollywood. Maras, por exemplo, ressalta como os conceitos de concepçâo - quando a ideia do filme é criada -e realizaçāo do filme - quando ocorre a sua filmagem - permitiriam um maior detalhamento das formas de práticas de roteiro dentro daqueles instantes. Assim, existiriam instantes em que haveria uma fronteira menor entre a concepçâo e a realizaçâo, como ocorreu no primeiro cinema, nas práticas próximas entre a escrita e a direçăo do cinema moderno, com ênfase nas experiências europeias, da nova Hollywood e dos cinemas novos do mundo inteiro, além, claro, de reverberar em modos mais atuais, sendo a escrita junto à realizaçăo uma prática comum em alguns cineastas e coletivos contemporâneos mundo afora. Por outro lado, a história e a prática dos estúdios de Hollywood estabeleceram uma paulatina separaçáo entre a concepçâo dramática e narrativa do filme, na etapa do roteiro no formato blueprint, e o seu instante de filmagem e ediçấo. Esse modelo revela-se contínuo e renovável na maior parte das formas de roteirizaçấo, por exemplo, que perpassam a televisâo, as séries de TV mais contemporâneas, algumas formas de animaçăo, assim como os roteiros que criam ambientes de imersăo em realidades virtuais, como os videogames, em que a programaçăo, em detrimento das "filmagens", revela-se como um instante bastante distante da criaçăo dramatúrgica.

Embora esses conceitos e essas periodizaçôes ainda sejam, aqui, apresentadas de forma geral e sem maiores (e necessários) detalhamentos, elas já nos encaminham

Além do modelo dos roteiristas free-lancer, que coliga o fim da era de ouro dos estúdios aos nossos dias, Steven Price salienta como dos anos 2000 em diante emerge o modelo do roteiro para captaçáo de recursos e como essa tônica criou uma rede internacional de fundos, seminários, supervisóes e orientaçōes de projetos, no formato de Sundance, que muda, inclusive, a forma de escrita e da narrativa do roteiro. Cf.: PRICE, 2013, p. 220. 
para uma compreensáo múltipla das práticas dos roteiros ao longo do século XX, indo além do perigo, constantemente disseminado e reproduzido pelos "manuais", de uma naturalizaçấo a-histórica dos roteiros. Nessa seara trata-se de um esforço que năo busca difundir regras e princípios genéricos, e destituídos de complexas matizes temporais, que acabam para reproduzir padróes dramáticos previamente tidos como eficientes. Ao contrário, a pauta dos estudos de roteiro concentra-se em deslindar os diálogos entre a narrativa e as práticas de roteiro nas suas minúcias, no seu dia a dia, e como elas mesmas podem ajudar a perceber formas de historizaçăo que impulsionem a uma efetiva autonomia entre a escrita e a narrativa e, daí em diante, busca-se organizar e impulsionar a invençăo distinta, a diferença da dramaturgia fílmica outras experimentaçōes, outros devires.

No segundo instante, no advento do chamado Director System, surge a sinopse, que seria uma forma de escrita extremamente sucinta, entre três e oito mil palavras, contendo o resumo da história do filme, de forma a guiar os trabalhos dentro do estúdio e pela equipe. $O$ terceiro instante e modo de roteirizaçáo seria o famigerado scenario que, primando pela continuidade do filme, se esforçaria em construir situaçóes, mais imaginárias, e, aos poucos, organizaria a narrativa numa série de eventos concatenados. Mais polêmico, o termo continuidade, que é o quarto de acordo com a cronologia e os destaques de Price, significou tanto um aspecto dramático do texto, que seria escrito já por um escritor considerado mais "sério", como uma possível modificaçăo no scenario recebido, o qual indicaria a dramaturgia textual necessária às etapas das filmagens (PRICE, 2013, p. 14). O quinto termo a ser pinçado das práticas históricas de roteiro é tratamento, que Francis Marion, uma das principais mulheres roteiristas do cinema mudo norte-americano, compreendia como sendo um instante intermediário entre a história do filme e a continuidade. ${ }^{6}$ Apenas relativamente recente, a partir dos anos sessenta e setenta, é que o termo Screenplay é adotado como uma terminologia comum, embora ele já surgisse separado como Screen Play ainda em 1916. No entanto, foi no período moderno que o Screenplay, num novo vocábulo, passou a significar uma etapa única, isolada, que năo se envolve diretamente com as filmagens. Por outro lado, o sétimo e último termo destacado, Shooting Script, sugeriria justamente as açôes e as organizaçōes já totalmente prontas e acessíveis às filmagens. ${ }^{7}$

Paulatinamente, entre periodizaçōes, formas de concepçăo e execuçăo e distintas terminologias, o fenômeno e as práticas de escritura para as telas passam a obter uma visibilidade e presença concreta em estudos de cinema e outras pesquisas acadêmicas similares. Fortemente influenciado pelos estudos genéticos, na literatura, Steven Price, na síntese e na conclusăo da sua história sobre o roteiro, propóe que compreendamos a escrita para filmes como um texto modular, que varia, adequa-se e, principalmente

6 É interessante salientar que, assim como ocorria com a montagem, o roteiro foi um dos primeiros ofícios com forte presença feminina na história do cinema. Francis Marion, por exemplo, é um caso de uma roteirista famosa, reconhecida no âmbito de Hollywood. No campo da UFA, na Alemanha, pode-se destacar o nome de Thea von Harbou, que colaborou com a primeira parte da obra de Fritz Lang, além de influenciar outros diretores do período.

$7 \quad$ Mesmo que ainda centrada em Hollywood o rol das terminologias e da pesquisa de Price também inclui as práticas de roteiro na Europa, com ênfase em países como a Inglaterra; a Alemanha e a Rússia durante o cinema mudo; a França, a Itália e a Suécia durante o cinema moderno, compartilhando, assim, uma interessante análise. 
adapta-se ao novos modelos e formatos, industrias e ou de imersăo criativa (PRICE, 2013, p. 236). Embora haja constantes convençōes, o roteiro - como forma, prática e história - também cria um interessante espaço de inovaçăo, propiciando incessantes rearranjos. Foram esses, por exemplo, os espaços criados por roteiristas da nova Hollywood que, na esteira dos roteiristas e autores independentes, trouxeram da França o formato do roteiro da master-scene (que opta por descrever a cena como um bloco dramático em vez de recortá-lo visualmente), mais literário, portanto, mais aberto aos comentários. Paralelamente, foi essa autonomia do roteirista que criou o espaço para o surgimento dos manuais de roteiro de Syd Field, a partir de 1979, com os quais os três atos, a trajetória mitológica do protagonista e a interioridade psicológica do personagem transformam-se em combinaçôes naturalizadas e amplamente aproveitadas por novas convençóes, novos formatos e novos contratados com, consequentemente, um novo instante na história dos estúdios e conglomerados de mídia nos Estados Unidos.

\section{Novos palimpsestos: do texto implícito ao roteiro explícito}

Há entre o papel e a tela - da tela aos textos (críticos ou acadêmicos) - mais mediaçóes do que supomos. Para além de uma história simplesmente cronológica do roteiro, os screenwriting studies também propiciam uma série de questionamentos críticos, os quais ainda estăo em desalinho. Săo pequenas e robustas crises que concernem questóes sobre o conceito do seu objeto; ou seja, de um certo debate sobre a ontologia do roteiro; das principais polêmicas acerca da autoria nos roteiros; e, por fim, resvala-se, direta ou indiretamente, em diversos aspectos tocantes à metodologia dos estudos de roteiro. Iniciemos pela metodologia. Existem algumas consequências extremamente interessantes que săo decorrentes dessa compreensăo do roteiro como um texto modular, com as quais, de forma discreta, Steven Price propóe uma instigante concepçăo teórico-metodológica que revisa aspectos dos estudos de cinema e dos estudos de adaptaçăo. O método da análise de filmes é, obviamente, o primeiro ponto a ser atingido. Se a ênfase da interpretaçâo da história do cinema, de filmes ou de autores privilegia o "acontecimento fílmico", durante o cerne da experiência cinematográfica ou audiovisual, o ponto de vista do roteiro (ou de outros estágios preparatórios à filmagem) também propiciaria uma quebra de unicidade nesses lances interpretativos. De forma recorrente, por exemplo, Price recorre aos roteiros de obras consagradas como Cidadâo Kane, Sunset Boulevard, Bonnie e Clyde e Easy Rider, entre outros, para dali, a partir dessa análise, textual e empírica, deslindar aspectos estéticos relevantes e que nâo migraram para o filme. Há, nesse cotejamento, uma outra relaçăo entre texto e jogo hermenêutico, com a qual o filme na tela năo é considerado como o texto final, mas como um texto outro, ou mesmo uma adaptaçáo, vejam bem, do próprio roteiro. Contudo, ao ser um texto dramático acabado, o roteiro pode, discretamente, criar uma crise de paradigma frente à unicidade de leitura da interpretaçâo textual do filme como circunscrito à tela.

A consequência imediata dessa compreensâo do roteiro como um pré-texto à mídia fílmica também engendra uma camada intermediária e condicionante à adaptaçấo, por exemplo, de obras literárias. Nesse ponto de vista, a análise direta de roteiros de 
adaptaçóes de romances, ou de outros gêneros literários, é capaz de iluminar aspectos que foram decisivos para as ideias e os conceitos que guiaram as adaptaçóes e as filmagens. De texto a texto, dos textos literários aos textos do roteiro - que sáo textos que năo querem mais ser textos ${ }^{8}-\mathrm{a}$ análise permite realmente o cotejamento de uma traduçăo com códigos similares que anunciam as etapas e as passagens, mais sutis e evidentes, da intermedialidade do roteiro ao filme. Ao fim e ao cabo, as preocupaçôes teórico-metodológicas mais latentes aos screenwriting studies tornam possível compreender um roteiro explícito, considerá-lo como um material singular, conotá-lo como visível e de transformá-lo numa etapa de relevância dramática e narrativa que năo pode ser suprimida do jeito que vem sendo. Os estudos com foco na análise fílmica, por outro lado, ensaiam, nos seus jogos interpretativos, em deslindar um roteiro implícito, o qual surge entre ilaçóes frente ao material final do filme; ilaçóes que buscam captar, de forma um tanto volátil - e arriscada - os principais aspectos das decisóes dramáticas.

O maior problema de apostar num roteiro implícito ao filme - que é uma prática, inclusive, seguida por boa parte dos autores dos manuais de roteiro ${ }^{9}$ - consiste tanto em desconsiderar os instantes da montagem como em negligenciar a autonomia das decisôes dramatúrgicas que estâo no texto e podem ou năo migrar ao filme. Eis que nos encontramos diante de um interessante paradoxo. O cerne do esforço dos estudos de roteiro está em ir além da metáfora do blueprint, a qual tende a limitar ao roteiro a uma cópia do filme - na compreensăo, mais restrita, de que se deve filmar como está escrito. Assim, a imagem na tela seria uma mera cópia e fidelíssima traduçăo do que estaria no roteiro, o que tornaria desnecessário retornar ao texto, ao roteiro e às formulaçôes dramatúrgicas que ainda estâo na página. Um tanto hercúleo, o esforço dos screenwriting studies está em enfatizar certa autonomia - textual, dramática e ontológica - do roteiro, seja na sua contribuiçăo à análise fílmica, seja na sua colaboraçâo à história do cinema, tanto na sua vertente cronológica quanto nos acontecimentos de força genealógica.

Para além da adaptaçấo, a segunda crise que vale destacar seria a da unicidade da autoria associada à encenaçăo. Sabe-se, desde os anos setenta, que houve a construçâo de um primeiro cânone no cinema concentrado prioritariamente nos diretores em detrimento de outros aspectos, seja de ordem estética, seja de fenômenos da complexa forma de inscriçăo autoral ou de sentido inerente ao cinema. $O$ primeiro aspecto a ser considerado é que a própria nouvelle vague, de onde veio a "política dos autores", nâo pregava uma anulaçăo da autoria do roteirista, por si, mas uma forma de diálogo com a literatura que também levasse em conta aspectos da linguagem cinematográfica (De BAECQUE, 2011; MARAS, 2008). O mote da uniăo entre o roteirista e o diretor reivindica tanto um afă de independência política em relaçăo ao diretor como uma forma de escrita estética (e fílmica) que visasse a uma maior aproximaçăo entre os instantes da concepçâo dramatúrgica e os da realizaçâo da obra, no instante da filmagem. Trata-se, na nossa leitura, de uma inquietaçâo de combinar a escritura literária com a linguagem

\footnotetext{
8 Como veremos mais adiante, Pasolini foi um dos primeiros a ressaltar ser o roteiro um texto - ou uma estrutura - que quer ser estrutura. Essa característica inflamável, volátil e evanescente do roteiro será essencial para seus vórtices conceituais.

9 Cf.: CANNITO, 2009, para um bom exemplo de um manual de roteiro embasado na análise fílmica.
} 
da imagem, dos sons e das mídias que convergem no cinema. Ao deixar de ser apenas literária, a escrita com a câmera multiplica-se e acabaria por cercar o ofício do escritor restringindo-o ao gabinete, aos livros e outros vícios de uma literatura previamente tida como de qualidade.

No entanto, mesmo complexificando esse panorama de surgimento do autor cinematográfico, o efeito da reconstruçăo histórica do cinema foi bem maior do que o imaginado. É nesse sentido que uma parte dos estudos de roteiro, por exemplo, esmera-se em descobrir e reconstruir nomes, artistas, roteiristas que podem ser lidos como autores da história do cinema. Um retrospecto na Alemanha de Weimar, num primeiro exemplo tomado ao acaso, nos conduz ao autor Carl Mayer, cujos roteiros - que eram lidos, publicados e divulgados - levaram à empolgaçăo de Lotte Eisner ao perceber, na sua concisâo poética e dramatúrgica, uma influência, entre seus trinta e seis roteiros, que permeou diretores como Friedrich Wilhelm Murnau, Karl Freund, Walter Rutmann, e Robert Wiene (para quem criou o doutor Caligari). Foi entre esses diretores que Mayer teceu elementos visuais e cênicos decisivos para a estética do cinema expressionista. Um segundo exemplo nos conduz à emergência do cinema moderno. A despeito das injustiças frente a Orson Welles e das recentes (à época) descobertas sobre plágio da crítica norte-americana, um dos ensaios mais antigos e polêmicos de Pauline Kael acabou por chamar a atençâo à obra de Herman Mankiewicz, que foi autor de inúmeras comédias nos anos trinta. Algo semelhante pode ser notado na contribuiçăo de Tonino Guerra, cujos roteiros passaram por diretores como Fellini, Tarkovski, Theo Angelopoulos, e, sobretudo, em alguns dos mais célebres filmes de Michelangelo Antonioni (PELO, 2010).

Haveria - e certamente há - vários outros roteiristas a serem destacados e estudados de forma similar à obra de renomados dramaturgos; ${ }^{10}$ alguns, como citamos, já sâo mais conhecidos e carregam essa mística aura de autores; outros, contudo, permanecem na penumbra da história, entre arquivos recônditos. Por fim, num cenário mais contemporâneo - e com um bom estudo brasileiro - vale lembrar da trajetória de Charlie Kaufman, que passou de menino prodígio do roteiro de Hollywood a um diretor enigmático (SAYAD, 2010) e que năo por acaso passeia pelas primeiras linhas desse ensaio.

Embora extremamente fecundo, pois pode suscitar interessantes revisóes críticas na história do cinema, o principal risco dessa ênfase do roteirista como autor seria uma incongruência frente ao fenômeno coletivo que é característico do ofício cinematográfico. ${ }^{11}$ Nessa esteira, destacar em demasia o roteirista como autor acarretaria, ao fim e ao cabo, a substituiçâo de um modo de autoria por outro, também restrito, também com

$10 \quad$ Num dos seus capítulos mais interessantes, Ian W. Macdonald (2013, cap. 7) reconstrói o notável, extenso e pouco conhecido trabalho ficcional e teórico do roteirista britânico Eliot Stannard, que foi o principal colaborador de Hitchcock ainda no seu período na Inglaterra.

11 A ênfase convencional na autoridade do roteiro ignora outros aspectos do trabalho que ocorrem no processo de roteirizaçăo. De acordo com Sergei Eisenstein, a expressāo "dicas para além do papel" é um lembrete de que o roteiro se refere apenas a uma ideia do filme que ocorre na cabeça. Deve-se considerar o processo do roteiro como se ele nos contasse mais sobre essas "dicas" do que sobre a obra final, quando na tela. Palimpsesto, mosaico, um patchwork, mesmo uma espécie de montagem literária, todos esses termos soam como mais apropriados do que a expressăo textual da ideia fílmica (screen idea), enquanto o termo blueprint torna-se redundante. No seu conjunto, a evidência textual do processo de roteirizaçáo surge como o ensaio do filme, propondo novas obras, assim como uma reflexáo na prática. (MacDONALD, 2013, p. 187, traduçáo nossa). 
seus problemas, epistemológicos e políticos. Ciente dessas disfunçōes, essas recentes pesquisas trazem à tona dois aspectos relevantes. Ainda impactado pela temática do cânone e pela aura genial do criador, emergem as relaçôes e mútuas influências entre o roteiro e a literatura, seja do ponto de vista textual, seja do aspecto da autoria. Paralelamente, Ian W. Macdonald propóe o conceito de Screen Idea Work Group para perceber como, na maior parte dos casos de escritura do roteiro há, sobretudo, um trabalho de grupo, que ele denomina como o avant-text, que conduz à ideia do filme, paralelo, independente, e que muitas vezes passa além da sua realizaçăo.

Como esses tópicos, contudo, resvalam no conceito sobre o roteiro? Num interessante e importante retrospecto, a pergunta sobre o valor literário do roteiro é uma das primeiras inquietaçôes que guiam o ensaio La Scenneggiatura come Struttura che Vuol Essere Altra Struttura, de Pier Paolo Pasolini, publicado em 1962 (PASOLINI, 2008). Situado num lugar de passagem, numa fronteira, o roteiro padeceria de uma definiçáo ambivalente. Como texto literário, ele seria incompleto, já que faz constante alusăo a um devir-filme. Como singularidade, possui apenas as suas notaçôes técnicas, que, obviamente, năo implementam um valor literário. No entanto, é pelo seu caráter ficcional, de fabulaçáo e imaginaçăo, que, para Pasolini, o roteiro coligaria o cinema a um empreendimento literário. O roteiro, nesse viés, consolida elementos estilísticos que buscam, ontologicamente, por uma transformaçăo; ou seja, por uma metamorfose da sua própria estrutura textual.

Inspirado por Pasolini, Steven Price acentua essas divergências entre a escrita literária dos gestos de escritura fronteiriços que caracterizam o roteiro. Price aglutina as diferenciaçôes entre texto e obra, oriunda de Barthes, e, nesse diapasâo, ressalta a pluralidade e a multiplicidade do texto em detrimento da obra, que é lançada numa teia de significados mais definida, fechada e circunscrita em si mesma. Abertos, os textos permitem novas versóes, remediaçóes, decantam as obras e inventam lugares novos, por onde a linguagem circula, de maneira livre e dinâmica (PRICE, 2010, p. 3238). Marcado, portanto, por essa tônica do processo textual, o roteiro năo consolida uma escrita acabada e definida e assim furta-se a obter um valor de uma obra. As concepçóes de tratamento e de adaptaçăo fazem parte desse rol de significaçôes, de textos sobrepostos, remendos necessários, cortes, supressôes, camadas e invençóes de ritmos dentro e fora do texto. Marcado pela reescrita, por novas versóes e por um devir-filme, o roteiro esquiva-se a uma assinatura que possa conotar concepçóes de obra ou, em última instância, de uma assinatura literária:

Nesse ponto de vista, o roteiro, que é forçado a aderir a formatos e convençōes preestabelecidas, transforma-se no revés de uma promessa. E, ainda assim, diante dessa perspectiva mais restrita, o roteiro é reescrito, de forma rotineira - o que é outra objeçáo familiar da tese do seu estatuto literário -, desde que renuncie à autoridade e aos seus direitos. (PRICE, 2010, p. 40, traduçăo nossa).

Nessa seara, a pergunta que continua pairando é sobre o valor de autoria do roteiro. Se há uma escritura predominantemente textual, entăo como ela poderia encadear obras? Seriam os roteiristas apenas autores passageiros de obras que acontecem nas telas? Complexas, tais indagaçóes ressaltam como o levantamento de obras de roteiristas náo deve estar restrito a um filme, ou dentro de um processo de filmagem, que seriam marcados por textos provisórios, sobrepostos a outros textos, numa dinâmica próxima a um palimpsesto. Contudo, é possível, sim, delinear uma obra como um 
conjunto coerente de traços estilísticos que ocorrem de forma recorrente entre tratamentos, roteiros, filmes e diretores. Por ser remota e discreta, essa construçâo de obras de roteiros é de fato paralela aos acontecimentos fílmicos e, na nossa compreensăo, só adquire uma visibilidade quando diante de esforços genealógicos ou quando imersas num debate entre arquivos e escrita, como é o caso, por exemplo, da especulaçăo do valor histórico de roteiros (ainda) năo filmados. ${ }^{12}$

Ainda nesse território de um texto em processo, Ian W. Macdonald propóe a utilizaçăo do termo da Ideia Fílmica (Screen Idea), como uma forma de captar um trabalho para as telas (screenwork) que seja potente, ainda náo concreto e que tenha no roteiro um dos seus pilares que sustentam as suas intençōes reais. Dinâmica e inclusiva a outros técnicos, a Screen Idea aproxima-se de um trabalho em grupo, mais preocupado em consolidar e definir o design do filme como um todo. "A ideia fílmica é um termo que nomeia aquilo que as pessoas pensam que estâo tentando criar... é aceitar que todos os textos disponíveis estăo relacionados com a ideia fílmica, na sua multiplicidade" (MacDONALD, S2013, p. 6). Sob o prisma do trabalho do autor, a principal decorrência da Screen Idea seria justamente o Screen Idea Work Wroup, que enfatiza e realça o trabalho de grupo, dinâmico, horizontal e que tem nas passagens entre o roteiro e o storyboard alguns dos seus profícuos documentos de pesquisa. Nessa perspectiva, o roteiro torna-se menos um elemento central do texto à obra, mas um índice privilegiado de captar a ideia geral do filme. No seu capítulo sobre o roteiro Nostromo, por exemplo, Ian W. Macdonald analisa o último trabalho de David Lean, que acabou năo sendo filmado, pois Lean faleceu durante o processo. De forma coerente, Macdonald investiga a ideia geral do filme entre os tratamentos do roteiro, o processo de storyboard, os relatos das reuniôes, as entrevistas e também a correspondência entre o diretor e o roteirista. Embora a concepçăo da "ideia" de um filme possa oferecer problemas epistemológicos evidentes, Macdonald é consciente de que năo haveria, nesses rastros de processos inconclusos, uma versâo mais importante que a outra, seja a dos roteiros ou as versôes dos filmes.

Nesse recorte, talvez uma das principais contribuiçōes do screenwriting studies seja justamente essa multiplicidade de análises que possibilita tanto uma quebra de alguns paradigmas dos estudos de cinema quanto a revalorizaçáo e o peso efetivo que o texto e os roteiros possuem como novas fontes empíricas. Diante desses desdobramentos, ainda emergentes, incita-se a novas configuraçôes teórico-metodológicas com as quais as relaçôes entre os textos e as obras, a escritura e a imagem, a estética e as tecnologias audiovisuais năo estejam restritas às heranças conceituais de autoria e experiência fílmica oriundas dos anos cinquenta e das décadas de institucionalizaçâo dos estudos de cinema (RODOWICK, 2007). Mais do que modulaçôes entre textos, as pesquisas sobre roteiros, estilos de escritura, seja do cinema independente seja da produçăo mais conectada aos estúdios de cinema e televisăo, necessitam de constantes entrelaçamentos entre a teoria, a história e as práticas de escrita para as telas que, segundo Steven Maras, propiciariam uma compreensăo precisa do problema inerente ao roteiro, como objeto de pesquisa (MARAS, 2008, p. 26).

12 Uma parte ainda em desenvolvimento da minha próxima pesquisa aborda justamente os aspectos fantasmáticos e especulativos dos roteiros năo filmados. Cf.: GONCALO, 2016a, 2016b. 


\section{O local da escritura fílmica: o roteiro como um gesto intermedial}

Mesmo seguindo as sugestões de Steven Maras, de uma coligação entre teoria, história e prática do roteiro, revelam-se tantas singularidades desse contexto cinematográfico e literário que é necessário, paradoxalmente, rever apenas alguns dos alicerces dos estudos de roteiro que esboçamos acima. Diante das minhas pesquisas fui incitado a rever o debate desse incipiente campo a partir de três grandes eixos. Há, primeiramente, a necessidade de estabelecer uma relaçăo de via de mâo dupla entre "o cinema, o roteiro e a literatura" - constantemente negligenciada pelos estudos acima citados - sobretudo ao entender a zona da escrita como um ponto de contato e fricçấo entre essas esferas. Numa segunda perspectiva, friso mais uma compreensáo intermedial do roteiro, o que acaba por aproximá-lo da intermedialidade, e, mais especificamente, à "teoria da mídia alemă". Percebe-se, nessa ênfase, que haveria uma diferença frente ao arcabouço teórico de Maras, Price e Macdonald, o qual dialoga mais com as tradiçóes conceituais francesas e norte-americanas. O terceiro campo que esboçarei nas próximas linhas encara um cotejamento entre o problema estético da "ekphrasis e o conceito de roteiro", de forma a enfatizar as passagens entre a palavra e a imagem, o verbo, as tecnologias de mediaçăo e as práticas de visualizaçăo engendradas pelas audiências, plateias e também pelos espectadores.

Como já vimos, os estudos de roteiro abordam os possíveis diálogos entre o cinema e a literatura de forma bastante específica e enfatiza, sobretudo, uma dinâmica textual intermediária entre os textos literários, a adaptaçăo e o texto do roteiro. Steven Maras, por exemplo, retorna aos ensaios de Béla Balàzs, para o qual o roteiro, ao longo do desenvolvimento tecnológico do cinema, surgiria como uma forma literária independente, algo, por exemplo, que aconteceu vagarosamente, ao longo de séculos, com o texto teatral (MARAS, 2008, p. 46). Instigante, a genealogia e a reconstruçáo histórica de Maras perpassa as consideraçóes sobre a autonomia ou a intermedialidade do texto do roteiro o que dialoga com as formulaçóes de James Boyle, Pasolini, Panofsky - para quem o roteiro năo teria autonomia além da sua performance - e John Gassner, que enfatizava as inovaçóes dramáticas do roteiro como mais relevantes que as literárias (MARAS, 2008, p. 59). Embora extremamente fecundas, essas contribuiçóes isoladas sáo lidas por Maras como uma forma de fisgar uma polêmica acerca de um possível status literário do roteiro. O que propomos, mais sutilmente, é respeitar a zona de ambiguidade e de intermedialidade, incompletude do texto do roteiro. Indo um pouco mais adiante, percebe-se como as práticas de roteiro incorporam e disseminam outras formas de escritura, novos hábitos de manejo dramático com mídias que, direta ou indiretamente, dialogam, influenciam, perturbam e alternam as práticas de escritura literária.

Trata-se, nessa perspectiva, menos de reconhecer o valor literário do roteiro do que perscrutar como o costume da escrita às telas alterna tanto hábitos dramáticos como formas de leitura e visualizaçăo. Nosso foco na escritura - compreendido dentro de um amplo panorama conceitual e geracional - propóe investigar vezos e verves que desfiguram práticas antigas e reconfiguram novos jogos entre a escrita, a imagem e as práticas de recepçâo. Por isso, em termos de história do cinema e da literatura, é possível descobrir uma gama de escritores que, a partir dos anos trinta, começaram a 
transitar entre os estúdios, como escritores-roteiristas, e estabelecem uma relaçáo de ida e vinda na linguagem literário-cinematográfica que julgamos potente e que ainda reivindica uma série de pesquisas mais detalhadas, seja pelo viés de cinematografias nacionais, seja pelos trânsitos intermediais entre formas de escrita. ${ }^{13}$

O segundo campo que criticamos nos estudos de roteiro decorre diretamente desses apontamentos. De maneira geral, as pesquisas e conceituaçōes acima apresentadas enfatizam mais o aspecto textual do roteiro do que as formas - narrativas e dramatúrgicas - que primam pela imagem. Mesmo quando lidam com a intermedialidade do roteiro, essas pesquisas năo vislumbram os códigos ou as formas de fabulaçăo imagética e da ambientaçâo visual que já estăo contempladas entre as palavras no papel. Por isso, as escrituras para as mídias - na nossa compreensăo - seriam as melhores formas de instaurar o roteiro dentro de um contexto tecnológico e expressivo mais amplo, que abarca outras mídias, como o rádio, e reverbera, direta ou indiretamente, nas dramaturgias para o palco, afetando, inclusive, as encenaçóes do chamado teatro pós-dramático (LEHMANN, 2007; FISCHER-LICHTE, 2004).

\section{A ekphrasis e o roteiro: velhos desafios, novos horizontes}

Na nossa pesquisa teórica sinalizamos e aportamos em direçăo à ampla e rica tradiçấo da ekphrasis. Como um local de passagem, como uma forma de escrita que se transcodifica em imagem - e entre imagens imaginadas e imagens vistas - algo que é constantemente traduzido em palavras. Detalharemos mais adiante as características da ekphrasis. Por ora, vale apontar que o roteiro transpóe justamente para a era das mídias um problema estético tradicional, que remete à Grécia Antiga, ao Renascimento e às formulaçôes da filosofia estética desde G. W. Lessing. Dessa forma - e diretamente influenciados pela latente perspectiva de ekphrasis na obra de Peter Handke e no seu panorama literário (GONCALO, 2016) - passamos, paulatinamente, a compreender o roteiro como uma ekphrasis e, no caminho inverso e simultâneo, a ekphrasis no contexto da hiper e intermedialidade contemporânea como um desdobramento das práticas de roteiro. Vale, nesse debate, evocar as formulaçóes de Rolf Dieter Brinkmann - influente poeta do novo subjetivismo alemăo que morreu precocemente. Num dos seus ensaios em que dialoga com as experimentaçôes da geraçăo beat norte-americana, ele afirma que o roteiro seria equivalente a um "filme em palavras" como, se, sublinearmente, a arte de descrever uma obra de arte por meio de palavras - como a ekphrasis é tradicionalmente concebida - estivesse no ínterim de uma metamorfose (BRINKMANN, 1982). Depois do filme, haveria apenas palavras numa rede ampla e infindável que, pelo discurso verbal, tenta reter e reconstruir o teor do fluxo fílmico. Antes do filme, contudo, quando as imagens ainda estăo estáticas, como esculturas imaginárias, figuras gestuais desprovidas de carne diegética, figuras fixas e imóveis no papel. Assim, a ekphrasis transforma-se num modo de leitura, numa forma de fabulaçăo visual, fronteiriça, que já năo é mais literatura e ainda năo se corporificou como filme.

13 No caso dos estudos entre escritores e roteiristas no Brasil vale destacar duas contribuiçôes seminais. Sâo elas de Vera Lúcia Follain Figueiredo e de Flora Sussekind. Cf.: FIGUEIREDO, 2010 e SUSSEKIND, 1987. 
Mais do que restrita ao roteiro, é preciso compreender o possível flerte com a ekphrasis como um gesto intermedial, uma forma de escrita que lida frontalmente com a passagem, a transformaçăo e a metamorfose. Aqui, a intermedialidade deixa de ser apenas um método de análise e evoca um horizonte estético, distante e consciente da chamada grande parataxis, mas sobretudo um gesto de mudança que é ciente da sua evanescência. Entra-se, a partir da ekphrasis até a consolidaçăo de uma escrita imagética e midiática, numa interessante e desafiadora fronteira, na qual vislumbra-se, com o roteiro, uma pré-história dessa escrita com mídias e códigos alfanuméricos e, consequentemente, constata-se uma certa pós-história de uma escrita circunscrita pela mimesis e representaçâo de eventos passados. É nesse limbo que a ekphrasis e o roteiro se encontram - e é um limbo que reivindica um maior detalhamento sobre o significado da era das mídias.

Ao realizar a sua genealogia das mídias, Friedrich Kittler destaca o papel essencial, nesse trajeto, desempenhado pela máquina de datilografar. Esse grifo nâo é casual. Juntamente com o gramofone e o filme, a máquina de escrever prenunciaria năo apenas a engenharia de Alan Turing, e a guinada da revoluçáo digital, mas, sobretudo, uma nova configuraçăo dos hábitos de escrita, que influenciaram a sociedade como um todo, impactando de forma indelével as formas de percepçōes do mundo. Como prática de escrita, o roteiro seria uma das culminâncias das três configuraçôes midiáticas ressaltadas por Kittler. Principalmente após 1928, com o advento do som no cinema, o roteiro revelaria uma das possíveis sínteses materiais, institucionais e de formas da escrita na consolidaçăo da era das mídias. Os hábitos da dramaturgia seriam herdados para o rádio e também se aglutinaria uma transiçăo proto-intermidiática única entre a literatura, o teatro e a pintura. Dessa forma, desvendar e elaborar a história das práticas de roteirizaçăo seria também uma maneira de melhor compreender as mudanças dos padróes de escrita, leitura e produçấo das imagens que surgiram do século XX em diante:

Um roteiro é algo híbrido: uma metade ainda é um texto de um drama a ser encenado e, como tal, descendente de Sófocles; a outra metade já é programaçăo de aparelhos e, como tal, antepassado dos programas calculados automaticamente por inteligência artificial. [...]. O desafio do roteirista é manter o equilíbrio entre uma escrita, que é iconoclasta, e uma escrita destinada às imagens. No entanto, o roteirista é um traidor, pois sucumbe à magia da imagem. [...] Ele năo escreve de acordo com a disposiçăo dramática, mas a escrita é um gesto dramático. Enquanto ele escreve seu roteiro, ele se contradiz. Ele é a vítima de uma dialética negativa especialmente perniciosa [...]. Muito em breve, năo se terá mais de ver imagens passarem em carruagens, e os roteiros abrirăo espaço para prescriçôes imagéticas codificadas de maneira mais funcional. Por isso, os roteiros săo um duplo engano: eles simulam ser textos, quando de fato sâo programas de imagens. (FLUSSER 2011, pp. 206-210)

Híbrido, traidor, dissimulado, vítima, contraditório e enganador, o roteiro, nessa generosa leitura de Flusser, mais parece uma prática diabólica do que um gesto poético. É justamente o seu perigo, seu espaço fronteiriço, que revela suas potencialidades. Ao enfatizarmos o roteiro - seus desafios conceituais, metodológicos e históricos (MARAS 2009) - optamos por descobrir uma escritura que já năo é mais apenas dramática e ainda nâo chega a ser uma programaçâo computacional. Situa-se, assim, numa zona intermediária, prenhe de fricçōes. 
Pretendemos salientar, nessa leitura de Flusser, como o roteiro acaba por incorporar o debate da ekphrasis. Nessa dinâmica, o roteiro seria o instante zero da visualizaçăo, a primeira traduçăo e transcriçăo entre as complexas roldanas cinematográficas. O roteiro năo está apenas atrelado ao papel, mas instala seu local de fabulaçăo estética entre a página e a tela; ou seja, ele insere o ato de escrita dentro de um sistema institucional e industrial, no qual, por um lado e pelo menos durante o período histórico do early cinema, o "primeiro cinema", afasta-se da literatura, para, em seguida, depois do advento do sonoro, buscar uma aproximaçăo com escritores, seja no seu formato livresco, seja na influência que o cinema acaba por exercer nos hábitos literários (MARAS, 2009, p. 46). O teórico húngaro Bela Balàzs foi um dos primeiros a perceber esta singularidade ontológica do roteiro, além das suas distinçôes frente ao teatro e à literatura:

\begin{abstract}
Balàzs náo subordina a arte do roteiro ao cinema, mas sugere uma diferente linhagem artística oriunda do drama. [...]. O roteiro náo é literário porque ele é parte do lado literário da produçăo, mas, ao invés disso, o roteiro torna-se uma forma literária única graças às demandas do cinema. Ele articula a existência paradoxal do cinema, "que é apresentar em palavras as experiências visuais do filme silencioso, que é algo que náo pode ser expresso em palavras". Ao inserir a produçăo de "efeitos visuais específicos", e năo efeitos literários no seio da criaçăo do roteiro, e da sua prática, Balàzs sublima as implicaçóes do paradoxo de representar a experiência visual por palavras. (MARAS, 2009, p. 47, traduçấo e grifo nossos).
\end{abstract}

Há, nesse trânsito do papel para a tela, mais do que uma mudança da materialidade. Tal como na ekphrasis, tenta-se tornar viva uma presença que, quando lida, está ausente. Como arquivo, o roteiro é mais do que a máscara mortuária da concepçăo, como Benjamin definiria a obra escrita (BENJAMIN, 2002, p. 115), mas, complementarmente, ao cristalizar imagens e sons por meio de suas palavras, ele busca reavivar fantasmas aos olhos dos seus leitores e futuros espectadores. Estamos diante de uma escrita sismográfica ou do eletrocardiograma de uma atmosfera dramático-visual, como Tonino Guerra definia o seu ofício (PELO, 2010, p. 121).

De um lado, a ekphrasis revelaria o aspecto de transiçăo da palavra para imagens e sons na tela - o que estaria próximo do que Flusser denomina programa. De outro lado, o roteiro seria o arquivo e o espelhamento dramático-visual de um acontecimento cinematográfico, um acontecimento em fluxo contínuo. Pensar, portanto, a ekphrasis pelo roteiro nos permite tanto uma compreensăo histórica e conceitual da dramaturgia cinematográfica quanto uma aproximaçăo com padróes de fruiçóes do espectador; como se, pelo roteiro e pela ekphrasis, a própria fantasmagoria cinematográfica revelasse parte da sua combustăo química. ${ }^{14}$

Em meio a tantas transformaçōes e inquietudes evoca-se, novamente, o filme Adaptaçâo de Spike Jonze, que percorreu as primeiras linhas deste artigo. Na obra o roteirista Charlie Kaufman multiplica-se numa série de duplos espelhados. Ele possui um irmáo gêmeo que se chama Donald o qual também é um roteirista. Se Charlie é o lado moderno, em crise com o roteiro, Donald, por sua vez, revela-se como o sujeito

14 Cf.: NELMES, 2011. Os Screenwriting studies também almejam delinear esses trajetos de colisăo da palavra (entre textos) e a imagem (entre mídias) que estáo circunscritos ao trabalho colaborativo entre roteiristas e diretores. 
pragmático, eficiente, que devora as páginas de Story, de Robert McKee, o "guru" dos manuais de roteiro, e consegue contar uma narrativa coerente, palatável, e agradável ao "público". Esses duplos traduzem com rara argúcia náo apenas os paradoxos da prática dos roteiros, como também do seu estudo como um objeto de pesquisa. Seja como roteirista, personagem ou duplo do irmáo gêmeo do escritor, Kaufman encarna desafios inconciliáveis, quando a escrita solicita compreensăo e inovaçấo. De forma paralela, os estudos de roteiro, embora ainda estejam esboçando seus primeiros passos, já começam a ver caminhos possíveis entre uma escrita modular, uma ideia fílmica, as distintas configuraçóes entre a prática e a história, seus gestos intermediais, suas ekphrasis, a vasta seara dos roteiros náo filmados e suas especulaçóes fantasmáticas. Como um texto que quer ser outro texto, como um roteirista - no caso de Kaufman e a sua "adaptaçăo" - que quer ser outro roteirista, os estudos de roteiro também apontam para esses devires, essas potências e latências de outras histórias do cinema que ainda nos săo possíveis de vislumbrar. Resta saber, por fim, como esse interessante campo de estudos ainda impactará nas futuras pesquisas de cinema, literatura, artes visuais e de novas mídias. Esse plot, contudo, ainda está em aberto e precisará ser escrito por muitas mâos. 


\section{Referências Biblográficas}

BORDWELL, David \& STAIGER, Janet. Narration in the fiction film. Madison: University of Wisconsin, 1985.

.The classical hollywood cinema: film style and mode of production to 1960. London: Routledge \& Kegan Paul, 1985. Routledge, 1985.

BRINKMANN, Rolf Dieter. Der Film in Worten. Hamburg. Rowohlt, 1982.

CANNITO, Newton \& SARAIVA, Leandro. Manual do roteiro ou Manuel: o primo pobre dos manuais de cinema e TV. Săo Paulo. Conrad Brasil, 2009.

CARRIERE, Jean-Claude. A linguagem secreta do cinema. Rio de Janeiro: Nova Fronteira, 2006.

DEBAECQUE, Antoine de. Cinefilia: invençâo de um olhar, história de uma cultura, 19441968. Săo Paulo: Cosac \& Naify, 2010.

EICK, Dennis. Drehbuchtheorien. Eine vergleichende Analyse. Konstanz: UKV, 2006.

FIELD, Syd. The screenwriter"s workbook. New York: Delta, 2006.

FIGUEIREDO, Vera Lucia Follain de. Narrativas migrantes: literatura, roteiro e cinema. Rio de Janeiro: PUC-Rio, 2010.

FISCHER-LICHTE, Erika. Culture as performances: theater history as culture history. Centro de Estudos de Teatro.

. Ästhetik des Performativen. Frankfurt: Suhrkamp, 2004.

FLUSSER, Vílém: A escrita: há futuro para a escrita? Săo Paulo: Anablume, 2011.

GONCALO, Pablo. 0 cinema como refúgio da escrita: roteiro e paisagem em Peter Handke e Wim Wenders. Sáo Paulo: Annablume, 2016.

. As espirais dos arquivos: lento retorno e as paisagens de um filme sem telas. Revista Galáxias, Sâo Paulo, v. 3, n. 33, 13 p. , 2016.

. Estilhaços da frase fílmica: a dramaturgia intermedial de Peter Handke. Revista Brasileira de Estudos da Presença, Porto Alegre, v .7, n. 2, 27 páginas , 2017.

GUMBRECHT, Hans Ulrich. Produçáo de presença: o que o sentido năo consegue transmitir. Rio de Janeiro: PUC-Rio, 2010.

HEFFERNAN, James A. W. Museum of words: the poetic of Ekphrasis from Homer to Ashbery. Chicago: The University of Chicago, 2004.

KAEL, Pauline. Criando Kane e outros ensaios. Rio de Janeiro: Record, 2000.

KITLER, Friedrich. Aufschreibesystem: 1800-1900. München: Fink Verlag, 1985.

. Gramophone, filme, typewriter. Stanford: Stanford University, 1999.

LEHMANN, Hans-Thies. Teatro pós-dramático. Săo Paulo: Cosac \& Naify, 2007.

LESSING, G. E. Laocoonte ou sobre as fronteiras da pintura e da poesia. Săo Paulo: Iluminuras, 1998. 
MARAS, Steven. Screenwriting: history, theory and practice. London \& New York: Wallflower, 2009.

MAcDONALD, Ian. Screenwriting poetics and the Screen Idea. London: Palgrave Macmilian, 2013.

McKEE, Robert Story. Substância, estrutura, estilo e os princípios do roteiro. Curitiba:Arte e Letra, 2006.

MICTHELL, W. J. Picture Theory: essays on verbal and visual representation. Chicago: University of Chicago, 1995.

MÜLLER, Adalberto. Linhas imaginárias: poesia, mídia e cinema. Porto Alegre: Sulina, 2012.

MULLER, Jürgen. Intermedialität und Medienhistoriographie. München: Wilhelm Fink, 2008.

NELMES, Jill (Org.). Analysing the screenplay. London: Routledge, 2011.

NORMAN, Marc. What Happens Next: A History of American Screenwriting. New York: Harmony Books, 2007.

PAECH, Joachim. Literatur und film. Stuttgart, Weimar, Metzler , 1997.

PASOLINI, Pier Paolo. Empirismo Hereje. Trad. Miguel Serras Pereira.Lisboa: Assírio \& Alvim, 1982.

PELO, RIIKKA. Tonino Guerra: the screenwriter as a narrative technician or as a poet of images? Authorship and method in the writer-director relationship. Journal of Screenwriting,. v. 1, is. 1, p. 113-129, 2010.

PRICE, Steve. A history of the screenplay. London: Palgrave Macmillan, 2013.

The screenplay: authorship, theory and criticism. 2010.

RODOWICK, D. N. The virtual life of film. Cambridge, MA: Harvard University, 2007.

SAGER EIDT, Laura. Writing and filming the painting: ekphrasis in literature and film. Amsterdam: Rodopi, 2008.

SARGENT, Epes Winthrop. The technique of the photoplay.New York: The moving picture world, 1913.

SAYAD, Cecília. 0 jogo da reinvençăo: Charlie Kaufman e o lugar do autor no cinema. Rio de Janeiro: Alameda, 2008.

SUSSEKIND, Flora. 0 cinematógrafo das letras: literatura, técnica e modernizaçăo no Brasil. Săo Paulo: Companhia das Letras, 1987.

WILLIAMS, Raymond. Drama em cena. Sāo Paulo: Cosac \& Naify, [1991] 2010. 